\title{
Attitude Towards Ageing Anxiety Among Different Age Cohorts in Anambra State, Nigeria
}

\author{
Theresa Chika Maduekwe \\ Department of Public Health, Madonna University, Nigeria \\ Golda O. Ekenedo \\ Department of Human Kinetics \& Health Education, \\ University of Port Harcourt, Nigeria
}

Doi:10.19044/esj.2018.v14n26p149 URL:http://dx.doi.org/10.19044/esj.2018.v14n26p149

\begin{abstract}
The study was aimed at investigating the attitude towards ageing anxiety among different age cohorts in Anambra State. Three research questions and two hypotheses guided the study. A cross sectional survey design was adopted for the study. The variables that influence the attitude were ascertained in line with the objectives of the study. The accessible population for the study consisted of all the different age cohorts from ten randomly drawn Local Government Areas in the state. The sample for the study consisted of 736 different age cohorts selected from the five education zones in the state. Multi-stage sampling procedure comprising cluster, simple random sampling, proportionate sampling and stratified random sampling were used in selecting the LGAs, towns and respondents. A validated Ageing and Attitude Scale Questionnaire (AASQ) designed by the researchers was used for data collection. The data were analyzed using frequencies and percentages as well as the chi-square. The hypotheses were tested at 0.05 level of significance using computer-based epidemiological Information (Ep/Info) version 6.1 software. The findings revealed negative attitude towards ageing anxiety among the different age cohorts. Gender of the subjects significantly influenced their ageing anxiety whereas ages of the subjects had no significant influence on their ageing anxiety. It was concluded that ageing education intervention is needed to bring about a positive change in attitude towards ageing anxiety.
\end{abstract}

Keywords: Attitudes, ageing, anxiety, age cohorts, aged elderly

\section{Introduction:}

Ageing and the ageing process are part of human experiences. Ageing is the process which commences at birth and continues through infancy, 
childhood, adolescence and adulthood to death (Hardt, 2009). It is the continuous wearing away and repair as well as replacement of body tissues to the stage when the repair and replacement of body tissues and replacement activities can no longer cope with the rate of wear and tear of the body (Udo, 2010). Chronologically, a person is regarded to be aged when he is 65 years or more (National Institute on Ageing - NIA, 2011). A person at this age of life may appear very old or younger depending on one's life-style.

According to World Health Organisation - WHO (2010), the pace and patterns of ageing in developing countries are without precedent. Unfortunately, ageing which is a natural process does not seem to be welcomed in developing countries. In Nigeria, people's regular prayer is that of long life, worst still people do not accept the alternative to ageing which is premature death (Hardt, 2009).

In contemporary Nigeria society, aging discussions are considered in bad taste and something to be avoided. This situation has raised vita questions in the minds of several educators. One such is how the modern Nigerian is able to cope with his own ageing especially on realizing that ageing is a natural process.

Kerlinger (2013) defined attitude as an organized predisposition to think, feel perceive and behave toward a referent or cognitive object. It is an enduring structure of beliefs that predispose the individual to behave selectively towards attitude referents category, objects, events, behaviours and even constructs.

Ageing as a biological process refers to all those time-dependent irreversible changes that lead to progressive loss of functional capacity after the point of maturity (Moody, 2011). Primary and secondary ageing processes are affected by anxiety. Primary ageing would describe those changes that oxxure over time, independent of any specific disease or trauma to the body, while secondary ageing would describe disabilities resulting from forces such as diseases (Greenberg \& Dinifiman, 2011).

Anxiety refers to feelings of apprehension that may stem from either real or imagined concerns (Davies, 2013 \& Litvak, 2009). It is a vague feeling that something bad is going to happen. Anxiety is related to fear but it is different from it. Hornby (2011) defined anxiety as nervous feeling caused by fear that something bad may happen. Depression can cause anxiety and a combination of anxiety and depression may lead to insomnia (sleeplessness).

Other features of anxiety include worry, tension, nervousness, being ill at ease, rapid pulse, sweaty palms and rapid breathing (Greenberg \& Dinitamon, 2011). Such circumstances range from person to person. Anxiety is likely to arise whenever the future is clouded by uncertainty and doubts. Ageing process is such fact that is clouded with uncertainties as individuals advance in age; they are faced with events and controversies for which the 
outcome is unpredictable and beyond control (Botwinck, 2014). Ageing process is also like entering into a new phase of life situation and individuals are never sure of what is expected of them.

Reports of studies by Hoelter \& Hoelter (2009); Feinsten (2010); and Flitcher (2011) identified two forms of anxiety namely: specific and general anxiety. Both affect ageing process. Specific anxiety includes stage fright while general anxiety includes feeling anxious most of the time regardless of where they are.

Severe disabling anxiety can be cured through professional help. This involves getting at the basic source of the anxiety. Process of ageing therefore needs to be properly explained to spell out anxiety situations. Relaxation, training and possible short-term use of tranquillizers were advocated by Myers (2011); Kalish (2010); Kaestenbaum (2009); Hoelter and Hoelter (2008). Other strategies of managing/coping with ageing anxiety for healthy ageing process include environmental planning, self-talk, and relabeling of priorities as well as moderate exercise regimen and systematic desensitization.

Environmental planning is the process of adjusting the environment (physical, biological, social, and emotional) to reduce the anxiety emanating from the environmental factors. Self talk can also be taken to manage the anxious feelings one might have about ageing. Relabeling involves changing the value or description ascribed to something (Hornby, 2008). Instead of seeing/perceiving the negative aspect of ageing, one can have a retrospect of his achievements before attaining that age.

Above all, the technique of systematic desensitization is useful in controlling ageing anxiety. The technique assumes that many forms of anxiety are learned and therefore can be unlearned. According to Greenberg and Dinitiman (2011), systematic desensitization involves the arrangement of anxiety-producing stimuli in a hierarchy or according to the anxious person that proceeds very gradually through the hierarchy in producing stimulus without fear. Therefore, viewing ageing as a stage in life from infancy through childhood and adulthood motivates healthy ageing, after all life is a metamorphosis from one stage to the other.

In developing countries like Nigeria and in Anambra State in particular, majority of the people much as they desire to live long do not really look forward to ageing (Troll, 2013). This may be because the public facilities for looking after the aged are non-existent. The very few old people's homes and geriatric wards where the aged are looked after by well trained nurses and social workers are owned by the private sector and awareness concerning their existence is very poor, and only the rich can afford them. Recreational facilities that would enable the aged to live productively and enjoyably are equally scarce. People are also not well informed of the ageing process. Many aged people suffer from many chronic diseases like diabetes, hypertension, 
and nervous disorder among others. There are also many social disabilities that affect the ageing process since every individual has certain distinguishing characteristics which are found in varying degrees among the elderly people such as: loss of status and an increased uncertainty about personal worth, including ageing anxiety.

People in Nigeria have different attitudes towards ageing but not much effort have been made to document these particularly in Anambra State. Based on the above, the study was designed to investigate the attitudes towards ageing anxiety of the different age cohorts in Anambra State.

\section{Purpose of the Study}

The purpose of the study was to investigate the attitudes towards ageing anxiety of the different age cohorts in Anambra State, with the following specific objectives:

1. To determine the attitude towards ageing anxiety among the different age cohorts in Anambra State;

2. To ascertain whether the attitude towards ageing anxiety among the different age cohorts in Anambra State is related to their gender.

3. To ascertain whether the attitude towards ageing anxiety among the different age cohorts in Anambra State is related to their age.

\section{Research Questions}

1. What is the attitude towards ageing anxiety among the different age cohorts in Anambra State?

2. What is the attitude towards ageing anxiety among the different age cohorts in Anambra State based on their gender?

3. What is the attitude towards ageing anxiety among the different age cohorts in Anambra State based on their age?

\section{Hypotheses}

1. There is no significant difference in the attitude towards ageing anxiety among different age cohorts in Anambra State based on their gender.

2. There is no significant difference in the attitude towards ageing anxiety among different age cohorts in Anambra State based on their age.

\section{Methods}

The cross sectional survey design was used for the study. This design which according to Babbie (2008) permits the collection of original 
information from a section of the population for the purpose of describing a population that is fairly large was used by Abanobi (2009) to ascertain the attitudes of mothers about etiology and management of febrile convulsion in children. The survey research design was therefore considered most appropriate for the present study because the prevailing attitudes of the different age cohorts were simply described as they exist in their natural setting.

The sample for the study consisted of 750 males and females from the different age cohorts randomly drawn from the ten Local Government Areas (LGAs) in Anambra State. Multi-stage sampling procedure was employed in drawing the sample. Each stage of the sampling was a prerequisite for selecting the sample in the next stage. Proportionate sampling technique was used in allocation of the subjects based on the five age cohorts of $12-21$ years, $22-31$ years, $32-41$ years, $42-51$ years and $56-61$ years. Seven hundred and fifty subjects were allocated to the age cohorts in the proportion of 5: 4: 3: $2: 1$.

The Ageing and Attitude Scale Structured Questionnaire designed by the investigators was the main instrument for data collection. The eighteenitem questionnaire has a five-point likert scale of Strongly Agree (SA); Agree (A); Neutral (N); Strongly Disagree (SD); and Disagree (D). Data were collected through administering the questionnaire to the subjects on face to face basis with the aid of ten literate trained research assistants, one from each of the ten selected LGA's of the State.

The content and face validity of the instrument was established by giving it to juror of experts in Public Health Education in Nigerian Universities. The final draft of the instrument was subjected to reliability testing using the test re-test technique. This was accomplished by administering fifty copies of the structured questionnaire to respondents from Aniocha LGA who were subsequently excluded from the study. A reliability index of .77 was obtained from the analysis of the data done using the Person Product Moment Correlation Coefficient. Data collected from 736 subjects (98.1\%) were computed using computer based Epidemiological Biological Information (EPI info) version 6.1 software. Appropriate cross tabulation of the dependent and independent variables yielded contingency tables that became the basis for testing the null hypotheses. Descriptive statistics of frequency and percentage were used to describe the attitude of the subjects towards ageing anxiety while Inferential Statistic of Chi-Square $\left(\chi^{2}\right)$ was used to test the variables at 0.05 alpha level of significance. 


\section{Results}

\section{Research Question 1:}

What are the attitudes toward ageing anxiety among different age cohorts in Anambra State?

Table 1: Attitudes toward ageing anxiety among the different age cohorts.

\begin{tabular}{|c|c|c|c|}
\hline \multirow{2}{*}{$\begin{array}{l}\text { S/No. } \\
\text { of Items }\end{array}$} & \multirow[t]{2}{*}{ Ageing Anxiety Concepts } & \multicolumn{2}{|c|}{ Attitude Responses } \\
\hline & & $\begin{array}{l}\text {-ve Negative } \\
\text { f }(\%)\end{array}$ & $\begin{array}{l}\text { +ve Positive } \\
\text { f }(\%)\end{array}$ \\
\hline 3. & $\begin{array}{l}\text { Recognizing that loss of respect, recognition and } \\
\text { approval accompany ageing worries me. }\end{array}$ & $626(85.1)$ & $110(14.9)$ \\
\hline 4. & $\begin{array}{l}\text { Whenever I see an aged person, I become worried } \\
\text { of what I will be in future. }\end{array}$ & $700(95.1)$ & $36(4.9)$ \\
\hline 5. & $\begin{array}{l}\text { If my sponsor dies as a result of old age, I will be } \\
\text { frustrated. }\end{array}$ & $690(93.8)$ & $46(6.3)$ \\
\hline 6. & I am often distress by the way time flies so rapidly & $600(81.5)$ & $136(18.5)$ \\
\hline 7. & $\begin{array}{l}\text { I don't have pleasant feeling of good } \\
\text { attainment/achievement due to ageing anxiety }\end{array}$ & $500(67.9)$ & $236(32.1)$ \\
\hline 8. & $\begin{array}{l}\text { I have no opportunity for self expression, } \\
\text { demonstration and self-esteem due to ageing and } \\
\text { anxiety. }\end{array}$ & $500(67.9)$ & $236(32.1)$ \\
\hline 9. & $\begin{array}{l}\text { It makes me nervous when people talk about } \\
\text { age. }\end{array}$ & $600(81.5)$ & $136(18.5)$ \\
\hline & $\begin{array}{l}\text { I am always worried of not accomplishing my } \\
\text { goals in life before getting old. }\end{array}$ & $496(67.4)$ & $240(32.6)$ \\
\hline & $\begin{array}{l}\text { I am disturbed because I am not provided with } \\
\text { a sense of responsibility date to ageism. }\end{array}$ & $700(95.1)$ & $36(4.9)$ \\
\hline 12. & I am easily distracted as a result of ageing anxiety & $500(67.9)$ & $236(32.1)$ \\
\hline 13. & I am easily irritated as a result of ageing anxiety & $700(95.1)$ & $36(4.9)$ \\
\hline 14. & I am excited as a result of ageing anxiety & $700(95.1)$ & $36(4.9)$ \\
\hline 15. & $\begin{array}{l}\text { I always suffer from fatigue due to worries } \\
\text { concerning ageing }\end{array}$ & $690(93.8)$ & $46(6.3)$ \\
\hline 16. & I am easily confused, due to the thought of ageing & $650(74.9)$ & $186(75.3)$ \\
\hline 17. & $\begin{array}{l}\text { I am sometimes moody, unhappy and at times in } \\
\text { anxious state of mind due to thought of ageing }\end{array}$ & $670(91.0)$ & $66(9.0)$ \\
\hline 18. & $\begin{array}{l}\text { I sometimes engage myself in some self destructive } \\
\text { behaviours, e.g., unabated smoking, drinking and } \\
\text { medication of known illness, due to the thought of } \\
\text { ageing }\end{array}$ & $600(81.5)$ & $136(18.5)$ \\
\hline
\end{tabular}

Negative (-ve) $=-608(82.4)$

Positive $(+\mathrm{ve})=128(17.1)$.

Based on the table above, 608 (82.6) of the subjects had negative attitudes toward ageing anxiety concepts, while 125 (17.4) had positive attitudes. 


\section{Research Question 2:}

What is the attitude towards ageing anxiety among the different age cohorts in Anambra State based on their gender?

Table 2: Chi-Square analysis of the attitude toward ageing anxiety among the different age cohorts in Anambra State based on their gender

\begin{tabular}{|c|c|c|c|c|c|c|}
\hline \multirow[b]{2}{*}{ Gender } & \multicolumn{3}{|c|}{ Attitude towards ageing anxiety } & \multirow[b]{2}{*}{$\chi^{2}$ cal } & \multirow[b]{2}{*}{$\chi 2 \mathrm{crit}$} & \multirow[b]{2}{*}{ df } \\
\hline & $\begin{array}{c}-v e \\
f(\%)\end{array}$ & $\begin{array}{r}+v e \\
f(\%) \\
\end{array}$ & Total & & & \\
\hline Male & $280(38)$ & $88(12)$ & $368(50)$ & & & \\
\hline Female & $328(44.6)$ & $40(5.4)$ & $368(50)$ & 16.78 & 3.841 & 1 \\
\hline Total & $608(82.6)$ & $128(17.4)$ & $736(100)$ & & & \\
\hline
\end{tabular}

The result of the table above showed that the calculated $\chi 2$ value was 16.78 with a crit. value of 3.841 at $1 \mathrm{df}$. This was significant at .05 level of significance in other words, there was significant difference between males and females cohorts in their attitude towards ageing anxiety. The null hypothesis was therefore rejected.

\section{Research Question 3:}

What is the attitude towards ageing anxiety among the different age cohorts in Anambra State based on their ages?

Table 3: Chi-Square analysis of the attitude towards ageing anxiety among the different age cohorts in Anambra State based on their ages.

\begin{tabular}{|c|c|c|c|c|c|c|}
\hline \multirow[b]{2}{*}{ Age interval } & \multicolumn{4}{|c|}{ Attitude towards ageing anxiety } & \multirow[b]{2}{*}{$\chi 2 \mathrm{crit}$} & \multirow[b]{2}{*}{ df } \\
\hline & $\begin{array}{c}-v e \\
f(\%)\end{array}$ & $\begin{array}{c}+v e \\
f(\%) \\
\end{array}$ & Total & $\chi^{2} \mathrm{cal}$ & & \\
\hline $12-21$ & $200(27.2)$ & $40(5.4)$ & 240 & & & \\
\hline $22-31$ & 168 (22.4) & $28(3.8)$ & 196 & & & \\
\hline $32-41$ & $120(16.3)$ & $30(4.1)$ & 150 & & & \\
\hline $42-51$ & $80(10.9)$ & $20(2.7)$ & 100 & 2.82 & 9.488 & 4 \\
\hline $52-61$ & $40(5.4)$ & $10(1.4)$ & 50 & & & \\
\hline Total & $555(75.4)$ & $181(24.6)$ & 736 & & & \\
\hline
\end{tabular}

P>.05

The result of the table above showed that the calculated $\chi 2$ value was 2.82 with a critical value of 9.488 at $4 \mathrm{df}$ and at .05 significant level. As the calculated $\chi 2$ is less than the critical value, the null hypothesis is accepted. In other words, there was no significant different in the attitude towards ageing anxiety among the different age cohorts in Anambra State based on age.

\section{Discussion}

The result of the respondents' attitude toward ageing anxiety (Table 1) indicates that $608(82.6 \%)$ subjects had negative attitude towards ageing anxiety, while $128(24.65 \%)$ had positive attitudes. The result was not 
expected. The researchers had expected that majority of the respondents should have had positive attitude towards ageing anxiety because of level of awareness being created on that through the mass media and seminars. These are expected to affect the cohorts' level of perception and conceptualization of the subject matter.

Significant relation existed on the male and female cohorts in their attitude towards ageing anxiety based on their gender (Table 2). The result revealed that $280(38 \%)$ of the male cohorts had negative attitudes; while 88 $(12 \%)$ had positive attitudes. Three hundred and twenty eight $(44.6 \%)$ of the female cohorts had negative attitude; while $73(9.91 \%)$ had positive attitudes. One would have expected that in this result, both the male and female cohorts could have shown positive attitudes due to previous experiences coupled with the fact that the awareness were created on ageing processes through the mass media.

The surprising finding was that males had lower negative attitudes than the female cohorts. The respondents might have fallen into their various categories of sex stereotypic attitudes which have direct or indirect consequences on the way each sex has viewed ageing and expressed those views. A second look at the central messages of the stereotypes designed by Stillon (2012) revealed that males are less expressive, deny and repress ageing related phenomena. Again, this finding can be justified by the fact that females being more conscious of their appearance and health may not be comfortable with the physical and physiological changes that come with ageing. This findings corresponds with the findings of Lowenthal and Haven (2008), Crase and Crase (2013), Kilander (2013) and Schroll (2014).

There was no significant difference in the attitude towards ageing anxiety among the different age cohorts in Anambra State based on their age (Table 3). One could have expected the respondents to have positive attitudes based on the different age intervals. Ageing anxiety attitudes are supposed to be positive as the ages of the respondents increase but unfortunately it was not so. It is possible that the relatively high levels of negative attitude towards ageing anxiety among the age interval of $12-21$ could be because of the fact that most of them were unaware of the ageing process. Awareness needs to be created. The findings correspond with the findings of Kilander (2013) and Schroll (2014).

\section{Conclusion:}

Based on the findings of this study it is concluded that negative attitude towards aging anxiety prevailed among the different age cohorts in Anambra State due mainly to lack of social welfare for the aged and lack of knowledge about the aging process. Hence, ageing education intervention can be 
beneficial in helping the public, especially female members, in terms of adopting a more positive attitudes towards ageing anxiety.

\section{References:}

1. Abanobi, C. C. (2009). Paradigm of assessments in health care service planning. Nigerian Journal of Social Sciences, 8 (2), $111-113$.

2. Babbie, E. R. (2008). The practice of social research. Belmonth: Wadswork Publishing Company Inc.

3. Best, J. W. (2011). Research in education. New Jersey: Prentice-Hall, Inc.

4. Botwick, J. (2014). Cognitive processes in maturity and old age. New York: Springer Publishing Company Inc.

5. Crase, D. R. \& Crase, D. (2013). Helping children understand ageing. Young Children, 32 (1), $21-25$.

6. Davies, B. M. (2013). Community health and social services. London: Holder and Sloughten Publishers.

7. Feinstein, A. (2010). Training the body to cure itself: how to exercise to heal. Pennsylvania: Rodale Press.

8. Filtcher, G. F. (2011). American health association medical scientific statement on exercise. Circulation, 86 (3), 340 - 344.

9. Gay, L. R. (2013). Education research competencies for analysis and application. Ohio: Charles E. Meril Publishing Company.

10. Greenberg, J. S. \& Dinitiman, G. B. (2011). Expanding the boundaries of wellness. New Jersey: Prentice - Hall Inc.

11. Hardt, D. V. (2009). Ageing: the final frontier. Eagle Wood Cliffs: Prentice - Hall Inc.

12. Hoelter, J. W. \& Hoelter, J. A. (2009). On the inter-relationships among exposure ageing and death, fear of ageing, death anxiety. Omega, 11, (3), $241-254$.

13. Hornby, A. S. (20011). Oxford advanced learner's dictionary of current English. Churia: Oxford University Press.

14. Kastenbaum, P. (2009). The vitality of ageing. Western port: Green Wood Publishing Company.

15. Kalish, R. A. (2010). Ageing, grief and careing relationships. Monterey: Brook/Cole.

16. Kerlinger, F. N. (2013). Foundation of behavioural research. New York: Holt, Reinhard and Winstern.

17. Kilander, H. E. (2013). Health for modern living. Eaglewood Cliffs: Prentice - Hall Inc.

18. Litvak, J. (2009). Ageing anxiety among university students in Northern Ireland and Canada. Journal of Psychology, 104, (3), 75 82. 
19. Lowenthal, M. F. \& Haven, C. (2008). The mid life transition: a period of adult psycho-social development. Psychiatry, 40, (1), $99-112$.

20. Moody, J. E. (2011). Ageing concepts and controversies. USA: Pine Terge Press.

21. Myers, J. E. (2011). Ethnic attitudes toward residential and nonresidential rural aged person. Psychological Reports, 43, 1235 -1238.

22. National Institute on Ageing (NIA) (2011). Information on ageing: Special Report on Ageing, No. 25. Michigan: Michigan Institute on Gerontology, Wayne State University Press.

23. Schroll, M. (2014). Assessment of health, self perceived health, chronic diseases and use of medicine, European Journal of Clinical Nutrition, 45, (3), 169 - 182.

24. Stillon, J. M. (2012). Ageing and sexes. Washington: Hemisphere.

25. Troll, L. E. (2013). Grand Parents: the family watch-dogs. In T. Brubaka (ed), Family relationships in later life. California: Wadsworth Press.

26. Udo, C. O. (2010). Death and dying education. Ibadan: Stiring Horden Publishers.

27. World Health Organisation (2010). Press office sheet population ageing: a public health challenge. WHO technical Series, 68, (3), 4 15. 